\title{
Death-associated Protein Kinase 1 Phosphorylates a-Synuclein at Ser129 and Exacerbates Rotenone-induced Toxic Aggregation of a-Synuclein in Dopaminergic SH-SY5Y Cells
}

\author{
Woo Hyun Shin and Kwang Chul Chung* \\ Department of Systems Biology, College of Life Science and Biotechnology, Yonsei University, Seoul 03722, Korea
}

\begin{abstract}
The formation of Lewy bodies (LBs), intracellular filamentous inclusions, is one of the hallmarks of Parkinson's disease (PD). a-Synuclein is the main component of LBs and its abnormal accumulation contributes to the pathogenesis of PD. Direct phosphorylation of $a$-synuclein at multiple Ser/Tyr residues is known to induce its aggregation, consequently promoting LB formation. Death-associated protein kinase 1 (DAPK1), originally identified as a positive mediator of $\gamma$-interferon-induced programmed cell death, possesses tumor-suppressive activity and mediates a wide range of cellular processes, including apoptosis and autophagy. Accumulating evidence suggests that DAPK1 is also associated with neuronal cell death and neurodegeneration. For example, DAPK1 phosphorylates tau and amyloid precursor protein, and induces tau aggregation and amyloid $\beta$ production, respectively, in Alzheimer's disease. DAPK1 is also accumulated to a larger extent in a mouse model of PD, causing synucleinopathy and dopaminergic neuron degeneration. In this study, we attempted to determine whether DAPK1 phosphorylates a-synuclein and affects cell viability in human dopaminergic neuroblastoma SH-SY5Y cells. We demonstrated that DAPK1 directly phosphorylates $\alpha$-synuclein at Ser129, and induces the formation of insoluble $\alpha$-synuclein aggregates. We also showed that DAPK1 enhances rotenone-induced aggregation of $\alpha$-synuclein, potentiating neuronal cell death. Taken together, these findings suggest that DAPK1 acts as a novel regulator of toxic $\alpha$-synuclein aggregation, possibly affecting and playing a role in the development of PD.
\end{abstract}

Key words: Death-associated protein kinase 1, a-Synuclein, Parkinson’s disease, Phosphorylation, Protein aggregation

\section{INTRODUCTION}

Parkinson's disease (PD) is one of the most common late-onset neurodegenerative diseases (NDDs), characterized by the loss of dopaminergic neurons in the substantia nigra pars compacta [1]. The formation of filamentous inclusion bodies called Lewy bodies (LBs) is the neuropathological feature of PD. The main component of these LBs is the protein $\alpha$-synuclein. Under normal conditions, a-synuclein is present in soluble form. However, in deadly patho-

Submitted April 9, 2020, Revised June 25, 2020,

Accepted June 25, 2020

* To whom correspondence should be addressed. TEL: 82-2-2123-2653, FAX: 82-2-312-5657 e-mail:kchung@yonsei.ac.kr logical conditions, $\alpha$-synuclein forms insoluble aggregates [2-4]. Moreover, $\alpha$-synuclein undergoes a variety of post-translational modifications, including phosphorylation $[5,6]$, nitrosylation [7], ubiquitination [8,9], and sumoylation [10], which impact a-synuclein oligomer formation and aggregation in different ways. In particular, hyperphosphorylation of $\alpha$-synuclein promotes the formation of LBs [11]. In healthy brains, only small fraction of a-synuclein is phosphorylated at S129 site (lower than 4\%), but its dramatic accumulation (approximately 90\%) has been observed in the brains of PD patients [12] or animal models of PD [13, 14].

Death-associated protein kinase 1 (DAPK1), a Ser/Thr kinase, acts as a positive regulator of apoptosis in response to various toxic stimuli, such as Fas, $\gamma$-interferon, and TNF- $\alpha$ [15-17]. Overexpression of DAPK1 increases formation of autophagic vesicles during programmed cell death [18]. Recent evidence suggests that
Copyright $\odot$ Experimental Neurobiology 2020. www.enjournal.org
This is an Open Access article distributed under the terms of the Creative Commons Attribution Non-Commercial License (http://creativecommons.org/licenses/by-nc/4.0) which permits unrestricted non-commercial use, distribution, and reproduction in any medium, provided the original work is properly cited. 
DAPK1 regulates cell death in the brain, and that the alteration of kinase activity is closely associated with NDDs [19]. For example, DAPK1 activation induces the phosphorylation of p53 at Ser23 [20], increasing apoptotic neuronal cell death [21, 22]. DAPK1 also regulates microtubule assembly, neuronal differentiation, and tau toxicity through the activation of microtubule-affinity regulating kinases 1 and 2 [23]. DAPK1 protein levels were highly upregulated in the brain of Alzheimer's disease (AD) patients [24]. In addition, DAPK1 increased the phosphorylation of AD-related tau protein, consequently causing the accumulation of tau protein and toxicity [24]. Furthermore, DAPK1 induces the phosphorylation of amyloid precursor protein (APP) at Thr668, and DAPK1knockout $(\mathrm{KO})$ mice displayed decreased amyloidogenic processing of APP [25]. In PD, the brains of 1-methyl-4-phenyl-1,2,3,6tetrahydropyridine-induced mice showed highly increased level of DAPK1 [26]. Furthermore, upregulation of DAPK1 stimulated degeneration of dopaminergic neurons, synucleinopathy, and the phosphorylation of $\alpha$-synuclein at Ser129 in a mouse model of PD [26].

In the present study, we examined the role of DAPK1 in a-synuclein phosphorylation, its aggregation, and cell viability in human dopaminergic neuronal cells. We found that DAPK1 directly binds to a-synuclein, phosphorylates $\alpha$-synuclein at Ser129, and increases the formation of detergent-insoluble and toxic a-synuclein aggregates in SH-SY5Y cells. In addition, rotenoneinduced aggregation of $\alpha$-synuclein followed by neuronal death was considerably attenuated in DAPK1-KO MEF cells. Taken together, these findings suggest that DAPK1 acts as a novel regulator of $a$-synuclein phosphorylation and toxic aggregation in dopaminergic neuronal cells.

\section{MATERIALS AND METHODS}

\section{Materials}

Dulbeccos modified Eagle medium (DMEM), fetal bovine serum (FBS), and Lipofectamine ${ }^{\circledR}$ LTX with PLUS reagent were purchased from Invitrogen (Carlsbad, CA, USA). Protein A-Sepharose beads were obtained from GE Healthcare Life Sciences (Piscataway, NJ, USA). Anti-c-Myc, anti-tubulin, anti- $\alpha$-synuclein, and antiGFP antibodies were purchased from Santa Cruz Biotechnology (Santa Cruz, CA, USA). Anti-FLAG and anti-DAPK1 antibodies were purchased from Sigma-Aldrich (St. Luis, MO, USA). Antiphospho-a-synuclein (S129) antibody was purchased from Abcam (Cambridge, UK). Anti-phosphoserine antibody, peroxidaseconjugated goat anti-rabbit and anti-mouse secondary antibodies were purchased from Millipore (Billerica, MA, USA). Alexa Fluor ${ }^{\circledR}$ 488-conjugated anti-mouse and Alexa Fluor ${ }^{\circledR}$ 594-conjugated anti-rabbit secondary antibodies were purchased from Invitrogen. Enhanced chemiluminescence (ECL) reagent was purchased from Abclon (Seoul, Korea) and Advansta (Menlo Park, CA, USA). All other chemicals used in the study were analytical grade commercial products and purchased from Sigma-Aldrich.

\section{DNA constructs and RNA interference}

Mammalian expression vectors encoding FLAG-tagged human wild-type DAPK1 (DAPK1-WT) and its kinase-inactive mutant having the substitution K42A (DAPK1-K42A) were kindly provided by T.H. Lee (Harvard Medical School, Boston, MA, USA). Human wild type $\alpha$-synuclein cDNA was subcloned into vector pEGFP to generate the construct pEGFP- $\alpha$-synuclein or into vector pcDNA3.1-Myc to generate Myc-tagged a-synuclein. Plasmids encoding $a$-synuclein mutants having the substitution of S9A, S42A, S87A, or S129A were generated by mutagenesis of pcDNA3.1-Myc- $\alpha$-synuclein. The plasmids encoding GST-fused wild type a-synuclein or its S129A point-mutants were produced by PCR amplification using PrimeSTAR HS DNA Polymerase (TAKARA, Shiga, Japan) and subcloned into pGEX4T-1 vector. All cDNA sequences were verified by DNA sequencing (BIONICS, Seoul, Korea). The $\alpha$-synuclein (SNCA)-specific small interfering RNAs (siRNAs) were designed and synthesized by Santa Cruz Biotechnology (sc-29619).

\section{Cell culture and preparation of cell lysates}

Mouse embryonic fibroblasts (MEFs) derived from DAPK1$\mathrm{KO}(D A P K 1-/-)$ and control $(D A P K 1+/+)$ mice were provided by T.H. Lee (Harvard Medical School, Boston, MA, USA). Human neuroblastoma SH-SY5Y cells were purchased from American Type Culture Collection (ATCC, Manassas, Virginia, USA). Cells were maintained in DMEM containing 10\% FBS and $100 \mathrm{U} /$ $\mathrm{ml}$ penicillin-streptomycin and grown at $37^{\circ} \mathrm{C}$ in a humidified atmosphere of 5\% $\mathrm{CO}_{2}$. All DNA transfections were performed using Lipofectamine ${ }^{\circledR}$ LTX with PLUS $^{\mathrm{TM}}$ reagent, according to the manufacturer's protocol. The cells were rinsed twice with ice-cold phosphate-buffered saline (PBS) and lysed in lysis buffer containing $50 \mathrm{mM}$ Tris ( $\mathrm{pH}$ 7.4), 1\% Nonidet P-40, $150 \mathrm{mM} \mathrm{NaCl}, 10 \%$ glycerol, and protease inhibitor cocktail including $1 \mathrm{mM} \mathrm{Na}_{3} \mathrm{VO}_{4}$, $1 \mu \mathrm{g} / \mathrm{ml}$ leupeptin, $1 \mu \mathrm{g} / \mathrm{ml}$ aprotinin, $10 \mathrm{mM} \mathrm{NaF}$, and $0.2 \mathrm{mM}$ phenylmethylsulfonyl fluoride.

\section{Primary cultures of cortical neurons}

All mice were handled in accordance with the guideline for animal care and use of Yonsei University. Cerebral cortices were removed from gestational day 14.5 mouse embryos (Orient BIO, Seongnam-si, Gyeonggi-do, Republic of Korea) and mechanically 
dissociated. Briefly, dissociated cortical cells were plated at a density of $5 \times 10^{6}$ cells per well of six-well plates that were precoated with $100 \mu \mathrm{g} / \mathrm{ml}$ poly-D-lysine and $1 \mu \mathrm{g} / \mathrm{ml}$ laminin (Invitrogen). Cultures were incubated at $37^{\circ} \mathrm{C}$ in Minimum Essential Medium (MEM, Fisher Scientific, Waltham, MA, USA) supplemented with $0.6 \%$ glucose, $1 \mathrm{mM}$ sodium pyruvate, $2 \mathrm{mM}$ L-glutamine, penicillin-streptomycin, and 10\% FBS in the atmosphere of $95 \%$ air and $5 \% \mathrm{CO}_{2}$. After $24 \mathrm{~h}$, culture medium was changed to Neurobasal medium (Invitrogen) supplemented with 2\% B-27 and $0.5 \mathrm{mM} \mathrm{L-}$ glutamine. At 4 DIV, cultures were treated with the indicated drugs that were dissolved in the same medium.

\section{Co-immunoprecipitation and immunoblot analysis}

Cell lysates containing $\sim 500 \mu \mathrm{g}$ protein were incubated overnight at $4^{\circ} \mathrm{C}$ with $0.5 \mu \mathrm{g}$ of the appropriate antibodies. Samples were incubated with Protein A-Sepharose beads for $2 \mathrm{~h}$ at $4^{\circ} \mathrm{C}$ with rotation. The beads were then pelleted and washed five times with lysis buffer. The immunocomplexes were boiled in SDS-PAGE sample buffer, resolved by SDS-PAGE, and transferred to nitrocellulose membranes. Membranes were blocked in Tris-buffered saline with Tween 20 (TBST) containing $50 \mathrm{mM}$ Tris (pH 7.4), $150 \mathrm{mM} \mathrm{NaCl}$, $0.1 \%$ Tween 20 , and $5 \%$ nonfat dry milk for $1 \mathrm{~h}$ at room temperature, and then incubated with the primary antibodies overnight at $4^{\circ} \mathrm{C}$ in $3 \%$ nonfat dry milk in TBST. The membranes were washed with TBST, incubated for $1 \mathrm{~h}$ with horseradish peroxidase (HRP)coupled secondary IgG, washed again with TBST, and visualized using ECL reagents (Abclon, Seoul, Korea). Grayscale images of immunoblotting data were quantified by MultiGauge V. 3.1 program (Fujifilm Life Science, Tokyo, Japan).

\section{Immunocytochemical analysis}

Cells were seeded onto Poly-L-lysine coated glass cover slips. After DNA transfection for $24 \mathrm{~h}$, the cells were washed twice with PBS (pH 7.4) and immediately fixed in 3.7\% formaldehyde for 10 $\mathrm{min}$ at room temperature. After fixation, the cells were permeabilized with $0.2 \%$ Triton X-100 for $10 \mathrm{~min}$ and blocked with $1 \%$ bovine serum albumin in PBS for $1 \mathrm{~h}$ at room temperature. The cells were then immunostained with the appropriate primary antibody, and Alexa Fluor ${ }^{\mathrm{TM}} 488$-conjugated anti-mouse and Alexa Fluor ${ }^{\mathrm{TM}}$ 594-conjugated anti-rabbit secondary antibodies were used to detect the primary antibodies. Images were captured using an LSM 700 laser scanning confocal microscope (Carl Zeiss, Oberkochen, Germany), and data were processed using a Zeiss LSM Image Browser (Carl Zeiss). To quantitate the colocalization of DAPK1 and $\alpha$-synuclein, Pearson's correlation coefficients were calculated using Image J software (National Institutes of Health, USA).

\section{Proximity ligation assay}

Proximity ligation assay (PLA) was performed with Duolink PLA assay kit (Sigma-Aldrich), following to the manufacturer's instruction.

\section{In vitro kinase assay}

SH-SY5Y cells were transfected for $24 \mathrm{~h}$ with plasmids encoding FLAG-tagged DAPK1-WT or its kinase-defective mutant (DAPK1-K42A). Cells were lysed in 1\% NP-40 lysis buffer and cell lysates were immunoprecipitated overnight at $4^{\circ} \mathrm{C}$ with anti-FLAG antibody. The immunocomplexes were incubated with $30 \mu \mathrm{l}$ of a 1:1 protein A-Sepharose bead suspension for $2 \mathrm{~h}$ at $4^{\circ} \mathrm{C}$ with gentle rotation. The beads were centrifuged and washed twice with lysis buffer and twice with kinase reaction buffer (40 mM Tris, pH 7.5, $20 \mathrm{mM} \mathrm{MgCl}_{2}$, and $50 \mu \mathrm{M}$ DTT). The samples were mixed with $2 \mu \mathrm{g}$ of bacterial recombinant GST-fused $\alpha$-synuclein and kinase reaction buffer containing $10 \mu \mathrm{M}$ ATP. The in vitro kinase reaction was initiated by the addition of $10 \mu \mathrm{Ci}\left[\gamma_{-}{ }^{32} \mathrm{P}\right] \mathrm{ATP}$. The reaction was allowed to proceed for $30 \mathrm{~min}$ at $30^{\circ} \mathrm{C}$ before termination by the addition of SDS-PAGE sample buffer. Protein samples were resolved by SDS-PAGE and the amount of incorporated $\left[\gamma^{-}{ }^{32} \mathrm{P}\right]$ was detected by autoradiography.

\section{Purification of bacterial recombinant a-synuclein protein}

The plasmids encoding GST-tagged $\alpha$-synuclein were expressed in Escherichia coli BL21 cells. Cells were cultured at $37^{\circ} \mathrm{C}$ until the $A_{600}$ reached $0.7 \sim 0.8$, and target protein expression was induced by addition of $0.5 \mathrm{~mm}$ isopropyl $\beta$-d-1-thiogalactopyranoside (IPTG) for $24 \mathrm{~h}$. Cells were harvested and lysed by sonication on ice in lysis buffer containing $50 \mathrm{mM}$ Tris- $\mathrm{HCl}$, pH 7.4, $200 \mathrm{mM}$ $\mathrm{NaCl}, 1 \mathrm{mM}$ EDTA, $1 \mathrm{mM}$ DTT, 0.1\%, Triton X-100, and protease inhibitor mixture. After centrifugation for $20 \mathrm{~min}$ at $12,000 \times \mathrm{g}$, the supernatant was incubated overnight at $4^{\circ} \mathrm{C}$ with glutathione Sepharose $4 \mathrm{~B}$ beads (GE Healthcare Life Sciences). Beads were then washed extensively with lysis buffer, and the recombinant proteins were eluted in elution buffer (50 mM Tris-HCl, $\mathrm{pH} 7.4$, and 10 $\mathrm{mM}$ reduced glutathione).

\section{Preparation of $1 \%$ Triton X-100-soluble and-insoluble frac- tions}

Cells were washed twice with ice-cold PBS and lysed in lysis buffer containing $10 \mathrm{mM}$ Tris (pH 7.4), 1\% Triton X-100, 150 $\mathrm{mM} \mathrm{NaCl}, 10 \%$ glycerol, $20 \mathrm{mM}$ N-ethylmaleimide, and protease inhibitor cocktail. Cell lysates were centrifuged at $15,000 \mathrm{~g}$ for 20 $\min$ at $4^{\circ} \mathrm{C}$. The supernatant was retained as the detergent-soluble fraction, and the pellet was washed twice with lysis buffer. The pellet was dissolved in lysis buffer supplemented with 4\% SDS and 
boiled for $30 \mathrm{~min}$ (referred to as detergent-insoluble fraction). Each sample was resolved by SDS-PAGE and the protein bands were visualized by immunoblot analysis.

\section{Filter trap assay}

Cell extracts containing approximately $500 \mu \mathrm{g}$ protein were applied onto cellulose acetate membranes with $0.2 \mathrm{~mm}$-pores that had been prewashed with PBS containing 0.1\% SDS. The membranes were then washed three times with PBS and stained with anti-Myc antibody. Sample staining was visualized by immunoblot analysis.

\section{Native gel electrophoresis}

Native gel electrophoresis was performed with lysates containing $\sim 20 \mu$ p protein, using the Native-PAGE ${ }^{\mathrm{TM}}$ Bis-Tris $4 \% \sim 16 \%$ precast minigel system (Life Technologies, Carlsbad, CA, USA), according to the manufacturer's instructions.

\section{Cell viability assay}

After DNA or siRNA transfection for $24 \mathrm{~h}$, cells were left untreated or treated with rotenone for additional $24 \mathrm{~h}$. The medium was removed and a 1:10 dilution of CCK-8 solution (Cell Counting Kit-8; Dojindo Laboratories, Kumamoto, Japan) in complete medium was added to the cells. Plates were incubated for $30 \mathrm{~min}$ at $37^{\circ} \mathrm{C}$, and the absorbance at $450 \mathrm{~nm}$ was measured using a microplate reader.

\section{Statistical analysis}

All statistical analyses were performed using an unpaired Student's t-test and the SPSS statistical analysis software (version 23.0) (IBM, Armonk, NY, USA). All values are expressed as the mean \pm standard error of the mean (SEM).

\section{RESULTS}

\section{DAPK1 binds to a-synuclein in human SH-SY5Y neuroblas- toma cells}

Based on the recent finding that DAPK1 acts as a novel regulator of synucleinopathy and dopaminergic neuron degeneration in a mouse model of PD [26], in the present study we examined whether DAPK1 mediates a-synuclein phosphorylation and aggregation in a dopaminergic neuronal cell line. We firstly examined whether there is a biochemical and functional interaction between DAPK1 and $\alpha$-synuclein. To determine if DAPK1 directly binds to $a$-synuclein in neuronal cells, SH-SY5Y cells were transfected with plasmid encoding Myc-tagged $\alpha$-synuclein or FLAG-tagged DAPK1 alone or together, and cell lysates were co- immunoprecipitated with anti-FLAG antibody. The immunoblot analysis of the samples with anti-FLAG antibodies revealed that ectopically expressed DAPK1 binds to a-synuclein (Fig. 1A). The biochemical interaction between endogenous DAPK1 and endogenous $\alpha$-synuclein was also confirmed in SH-SY5Y cells (Fig. 1B). Moreover, interaction between endogenous DAPK1 and endogenous $\alpha$-synuclein was verified in mouse primary cortical neurons (Fig. 1C). Furthermore, immunocytochemical analysis of SH-SY5Y cells revealed that overexpressed FLAG-DAPK1 and GFP- $\alpha$-synuclein are colocalized, primarily in the cytosolic area, with a Pearson's correlation coefficient of 0.58 (Fig. 1D). The colocalization of endogenous DAPK1 and $\alpha$-synuclein was further confirmed with immunocytochemical analyses (Fig. 1E) and proximity ligation assay (Fig. 1F).

\section{DAPK1 directly phosphorylates a-synuclein on Ser129}

Because the phosphorylation of $a$-synuclein, especially at Ser129, is important for aggregate formation [5], we next examined whether DAPK1 directly phosphorylates a-synuclein on Ser129 in SH-SY5Y cells. Overexpression of DAPK1 caused a significant increase in the level of S129-phosphorylated $\alpha$-synuclein. However, this effect was not seen with the DAPK1-K42A mutant (Fig. $2 \mathrm{~A}$ ), indicating that DAPK1 increases the phosphorylation of $\alpha$-synuclein at Ser129 in a kinase-dependent manner.

Previous research indicates that rotenone treatment of SH-SY5Y cells induces phosphorylation of $\alpha$-synuclein on Ser129, enhancing aggregation of $\alpha$-synuclein [27]. Based on this finding, we further examined whether the phosphorylation state of $a$-synuclein induced by rotenone is differentially affected in DAPK1-WT MEF and DAPK1-KO MEF cell lines. In both cell types, the amount of $\alpha$-synuclein phosphorylation at Ser 129 was increased by rotenone (Fig. 2B). However, it was increased to a lesser extent in DAPK1KO MEFs than DAPK1-WT MEFs (Fig. 2B). Next, in addition to Ser129, we determined whether DAPK1 phosphorylates other Ser residue(s) within $\alpha$-synuclein, which possesses a total of four Ser residues at positions $9,42,87$, and 129 . Whereas overexpression of DAPK1 induces the phosphorylation of wild-type $\alpha$-synuclein at Ser residue 129, this phenotype was not seen in cells expressing the $\alpha$-synuclein-S129A mutant (Fig. 2C). However, compared with cells transfected with wild-type $\alpha$-synuclein, cells expressing the a-synuclein-S9A, -S42A, and -S87A mutants showed no difference in the amount of phosphorylated $\alpha$-synuclein (Fig. 2C). These results suggest that DAPK1 specifically induces $\alpha$-synuclein phosphorylation at S129.

To demonstrate that DAPK1 directly phosphorylates $\alpha$-synuclein at Ser129, an in vitro kinase assay was performed. SH-SY5Y cells were either mock-transfected or transfected with plasmid encod- 
A

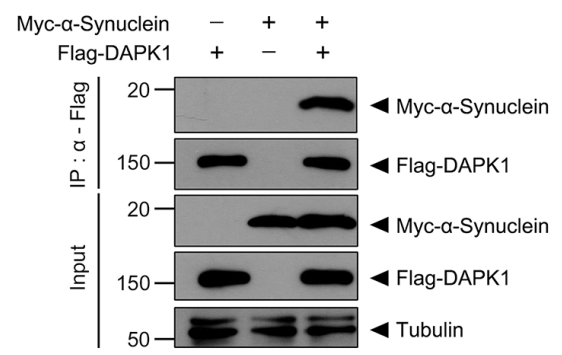

B

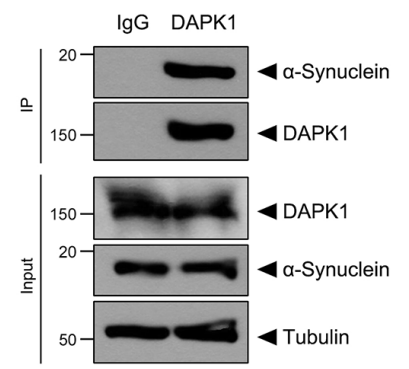

C

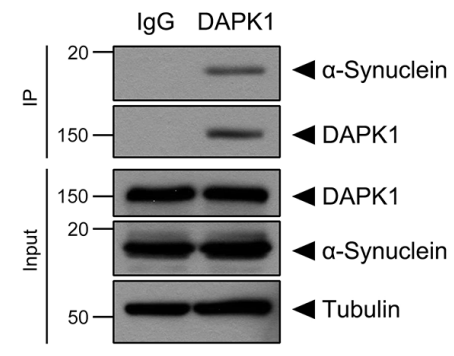

$\mathbf{F}$

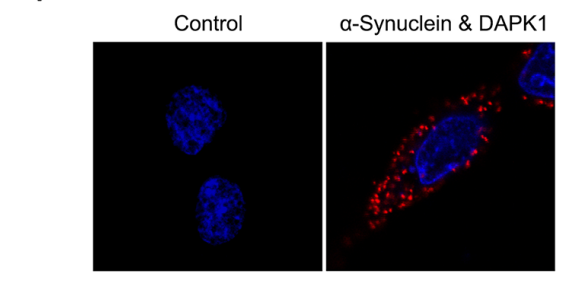

C

F
D
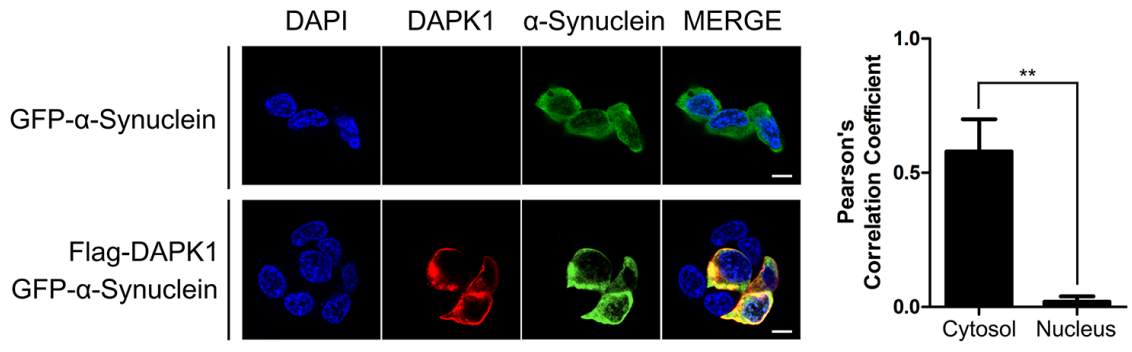

E DAPI DAPK1 $\alpha$-Synuclein MERGE

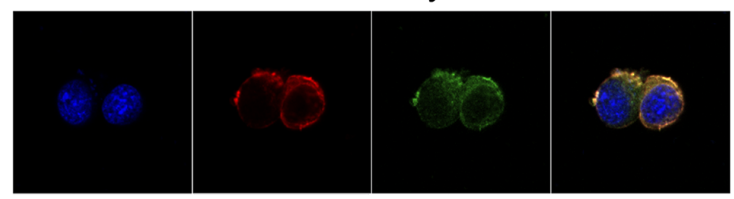

Fig. 1. DAPK1 binds to $a$-synuclein in human dopaminergic SH-SY5Y cells. (A) SH-SY5Y cells were transfected with plasmids encoding Myc- $a$ synuclein and/or FLAG-DAPK1 for $24 \mathrm{~h}$. Total cell lysates were immunoprecipitated with anti-FLAG antibody, followed by immunoblotting with antiMyc or anti-FLAG antibodies. Tubulin served as a loading control. (B) SH-SY5Y cell lysates were immunoprecipitated with anti-DAPK1 antibody, followed by immunoblotting with the indicated antibodies. Where indicated, cell lysates were immunoprecipitated with pre-immune IgG as a negative control. (C) Mouse primary cortical neurons were immunoprecipitated with anti-DAPK1 antibody, followed by immunoblotting with the indicated antibodies. Where specified, cell lysates were immunoprecipitated with pre-immune IgG as a control. (D) Representative confocal images of immunostaining of GFP- $\alpha$-synuclein (green) and FLAG-DAPK1 (red) are shown. Scale bar=10 $\mu \mathrm{m}$. Pearson's correlation coefficient of the colocalization of $\alpha$-synuclein and DAPK1 was calculated using Image J software. Data represent the mean \pm standard error of the mean (SEM) of five independent experiments ( $\left.{ }^{* *} \mathrm{p} \leq 0.01\right)$. (E) Representative confocal images of immunostaining of endogenous $\alpha$-synuclein (green) and DAPK1 (red) are shown. (F) Proximity ligation assays were performed either without antibody (control) or with the primary antibodies of $a$-synuclein and DAPK1.

ing FLAG-tagged wild-type DAPK1 or its kinase-defective mutant, and cell lysates were immunoprecipitated with anti-FLAG antibody. In vitro kinase assays of anti-FLAG immunocomplexes with the recombinant $\alpha$-synuclein as a substrate demonstrated that DAPK1-WT directly phosphorylates $\alpha$-synuclein, whereas this effect was not seen with the DAPK1-K42A mutant (Fig. 2D). Moreover, the $\alpha$-synuclein-S129A mutant was not phosphorylated at all by wild-type DAPK1 (Fig. 2E).

Taken together, these results indicated that DAPK1 directly phosphorylates $\alpha$-synuclein at residue Ser 129.

\section{DAPK1 increases a-synuclein aggregation in SH-SY5Y cells}

Because the phosphorylation of $\alpha$-synuclein at S129 is known to stimulate the formation of its insoluble aggregate $[3,11]$, we next determined whether DAPK1 affects $\alpha$-synuclein aggregation in SH-SY5Y cells. Firstly, filter trap assay revealed that the amount of $\alpha$-synuclein aggregate was markedly increased by exogenous DAPK1 in a dose-dependent manner (Fig. 3A). However, overexpression of the DAPK1-K42A mutant had no effect on $\alpha$-synuclein aggregation (Fig. 3A). Moreover, the $\alpha$-synucleinS129A mutant did not form notable aggregates, compared with wild-type a-synuclein (Fig. 3B). These results are consistent with the previous finding [3]. Furthermore, aggregation of the 
A
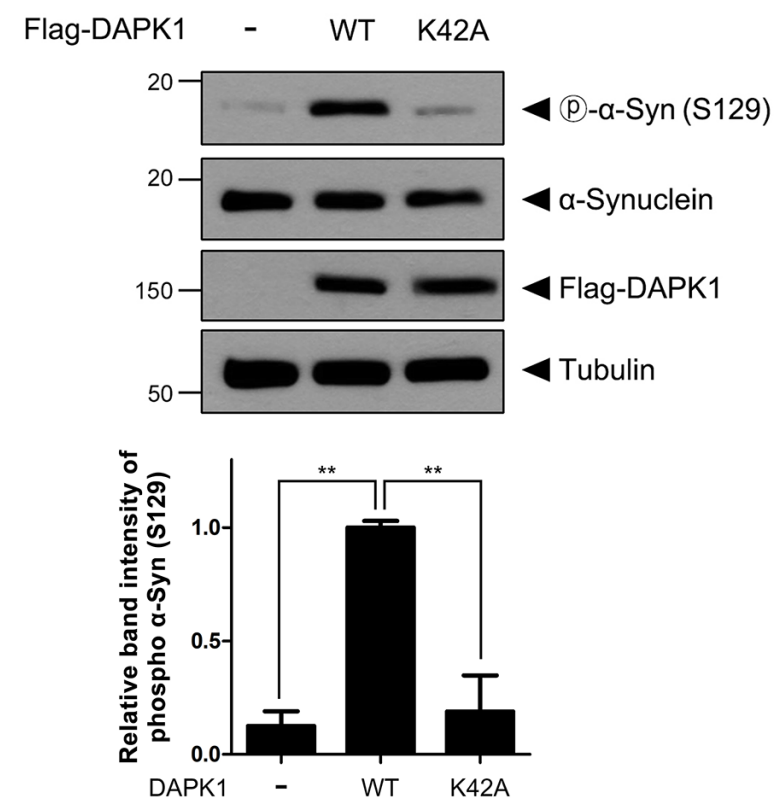

C
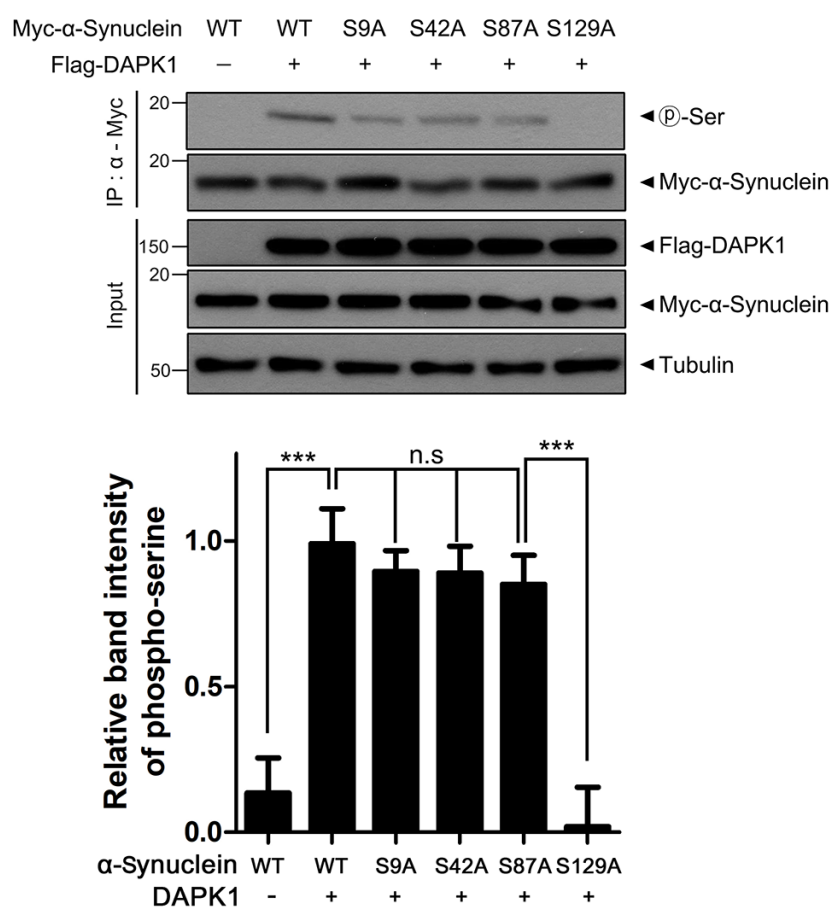

B

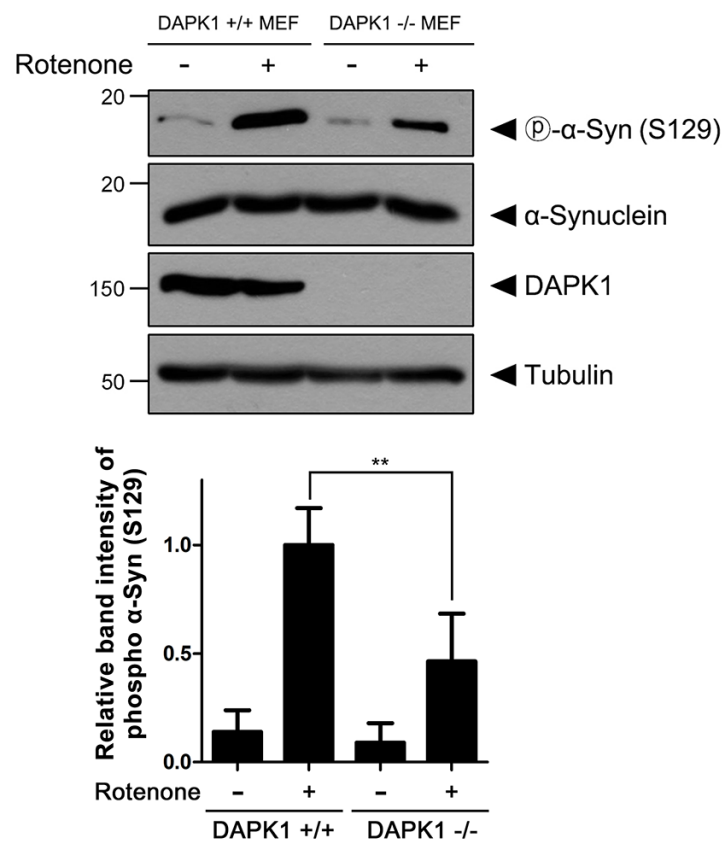

D

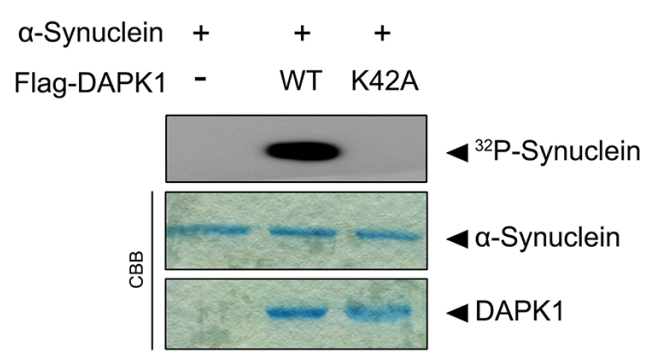

E
a-Synuclein WT WT S129A

Flag-DAPK1 - ++

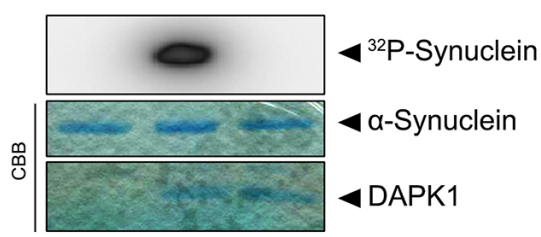

Fig. 2. DAPK1 directly phosphorylates a-synuclein at Ser129. (A) SH-SY5Y cells were either mock-transfected or transfected for $24 \mathrm{~h}$ with plasmid encoding FLAG-tagged wild-type DAPK1 (DAPK1-WT) or its kinase-defective mutant having the point mutation K42A (DAPK1-K42A). Cell lysates were immunoblotted with the indicated antibodies. (B) DAPK1-WT mouse embryo fibroblasts (MEF) or DAPK1-KO MEFs were treated either DMSO (control) or $100 \mathrm{nM}$ rotenone for $24 \mathrm{~h}$. Cell lysates were immunoblotted with the indicated antibodies. (C) SH-SY5Y cells were transfected with plasmids encoding FLAG-DAPK1 and/or various point-mutants of Myc- $a$-synuclein. Cell lysates were immunoprecipitated with anti-Myc antibody, followed by immunoblotting with the indicated antibodies. All graphed data represent the mean \pm SEM of five independent experiments $\left({ }^{* *} \mathrm{p} \leq 0.01\right.$; $\left.\mathrm{a}-\mathrm{c}\right)$. Statistical analyses were performed using the SPSS Statistics software (version 23.0) (IBM). (D, E) After SH-SY5Y cells were transfected for $24 \mathrm{~h}$ with plasmids encoding FLAG-tagged DAPK1-WT or DAPK1-K42A mutants, in vitro kinase assay of cell lysates was performed. 
A

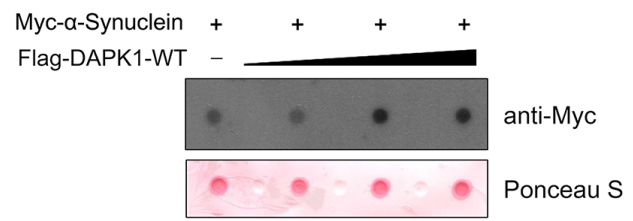

Myc- $\alpha-S y n u c l e i n+\quad+\quad+$ Flag-DAPK1-K42A

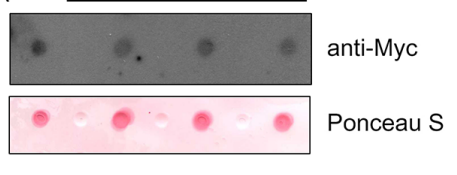

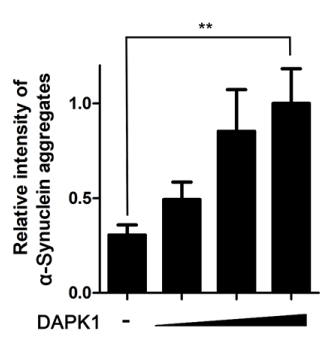

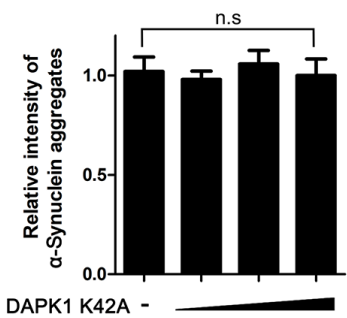

B

$\begin{array}{rrrrr}\text { Myc-a-Synuclein } & \text { WT } & \text { WT } & \text { S129A } & \text { S129A } \\ \text { Flag-DAPK1 } & - & + & - & +\end{array}$
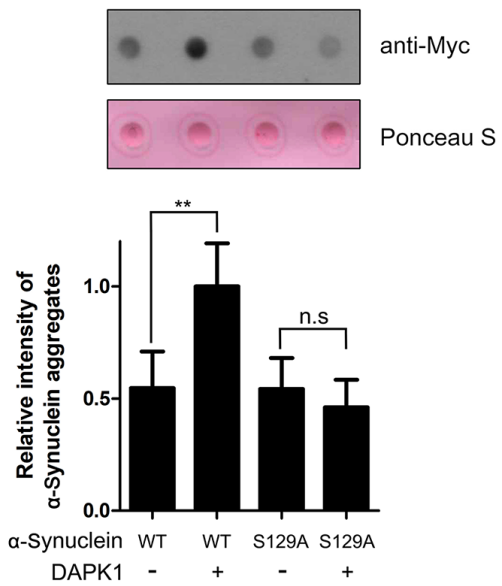

C
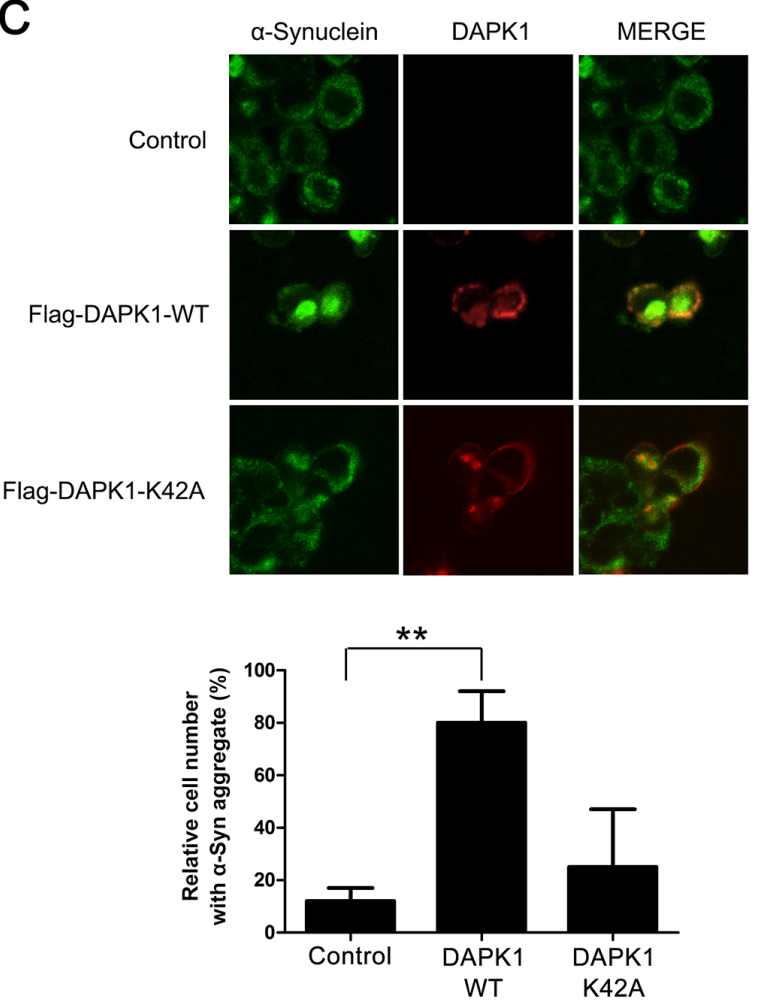

D

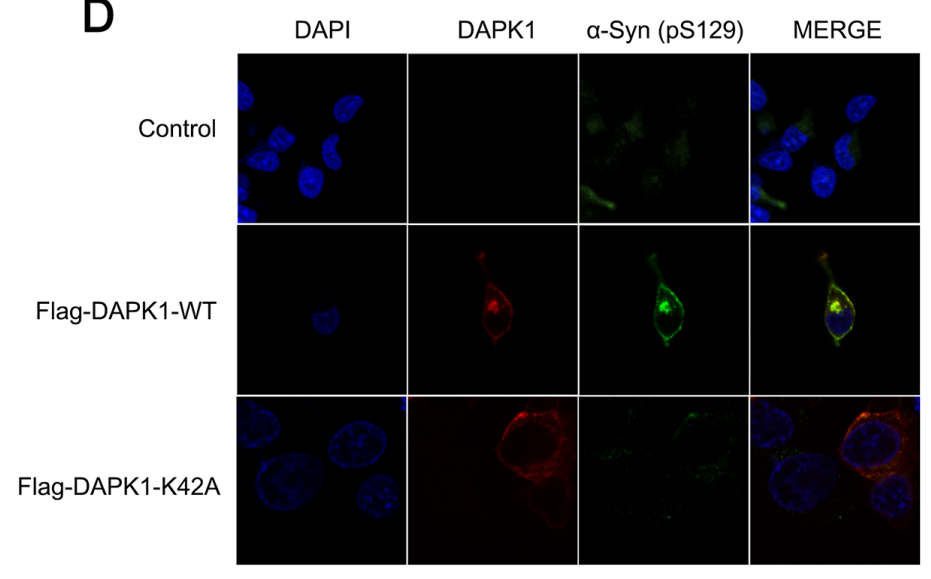

Fig. 3. DAPK1 promotes $\alpha$-synuclein aggregation in SH-SY5Y cells. (A) After SH-SY5Y cells were transfected for 24 h with plasmids encoding Myc-asynuclein alone or with increasing amounts of FLAG-DAPK1-WT or FLAG-DAPK1-K42A, filter trap assay of cell lysates was performed. (B) SH-SY5Y cells were transfected for $24 \mathrm{~h}$ with plasmids encoding Myc- $\alpha$-synuclein or Myc- $\alpha$-synuclein-S129A, or FLAG-DAPK1 alone or in combination. Cell lysates were prepared, and filter trap assay was performed. (C) Representative confocal images of the immunostaining of GFP- $\alpha$-synuclein (green) and FLAG-DAPK1 (red) are shown. The number of cells showing visible $\alpha$-synuclein aggregates versus the number showing no-apparent granular inclusions was calculated and the percent ratio is shown as a graph. (D) Representative confocal images of the immunostaining of pS129- $a$-synuclein (green) and FLAG-DAPK1 (red) are shown. The number of cells showing visible a-synuclein aggregates vs the number of cells showing no-apparent granular inclusions was calculated, and their percent ratios are shown as a graph. All graphed data represent the mean \pm SEM of five independent experiments $\left({ }^{* *} \mathrm{p} \leq 0.01\right.$; a-d). 
a-synuclein-S129A mutant was unaffected by DAPK1-WT (Fig. 3B). Lastly, immunocytochemical analysis of SH-SY5Y cells revealed that DAPK1 overexpression increases the formation of intracellular $\alpha$-synuclein inclusions (Fig. 3C), whereas DAPK1$\mathrm{K} 42 \mathrm{~A}$ caused no measurable change in formation of inclusions (Fig. 3C). Especially, the immunocytochemical analysis of the samples with phospho-a-synuclein antibody (S129) revealed that DAPK1 overexpression increases the formation of pS129- $\alpha$ synuclein-containing inclusions (Fig. 3D).

These results suggest that DAPK1 acts as positive regulator of a-synuclein aggregation.

\section{DAPK1 increases rotenone-induced synucleinopathy in mammalian cells}

Next, we determined whether DAPK1 acts as a novel regulator of rotenone-induced synucleinopathy in neuronal SH-SY5Y cells. Because rotenone treatment induces toxic aggregation of a-synuclein [27], we firstly checked whether DAPK1 affects the formation of high molecular weight $\alpha$-synuclein aggregate in response to rotenone. SH-SY5Y cells were either mock-transfected or transfected with plasmid encoding FLAG-tagged DAPK1. After treatment with rotenone, cell lysates were sequentially extracted with lysis buffer containing 1\% Triton-X100 (detergent-soluble fraction) and 4\% SDS (detergent-insoluble fraction). Immunoblot of cell lysates with anti- $\alpha$-synuclein antibody demonstrated that DAPK1 increases $\alpha$-synuclein aggregation in the detergent-insoluble fraction (Fig. 4A). Then, we performed Native-PAGE to determine if DAPK1 affects the formation of rotenone-induced soluble oligomers of $\alpha$-synuclein as well as aggregates. Whereas rotenone treatment induced formation of $\alpha$-synuclein oligomer in the control DAPK1-WT MEFs (Fig. 4B), oligomer level was significantly decreased in DAPK1-KO MEFs by more than 70\% (Fig. 4B). We further checked whether these results are similarly observed in immunocytochemical analysis. As shown in Fig. 4C, $\alpha$-synuclein aggregate formation was significantly increased in DAPK1-WT MEFs by 2.6-fold, compared to DAPK1-KO MEFs (Fig. 4C). However, addition of exogenous DAPK1-WT to DAPK1-KO cells restored the formation of $\alpha$-synuclein aggregates by approximately 2 -fold (Fig. 4C). Especially, the formation of pS129-a-synucleincontaining aggregates was significantly increased in DAPK1-WT MEFs, compared to DAPK1-KO MEFs. Then, the addition of exogenous DAPK1-WT to DAPK1-KO cells restored the formation of pS129- $\alpha$-synuclein aggregates by approximately 2.5 -fold (Fig. $4 \mathrm{D})$.

Finally, we examined whether DAPK1-mediated $\alpha$-synuclein aggregation changes relative cell viability upon rotenone treatment in SH-SY5Y cells. CCK assay of the samples revealed that overexpres- sion of DAPK1 alone does not significantly affect cell death (Fig. $4 \mathrm{E}$ ). In addition, rotenone treatment causes toxic synucleinopathy in SH-SY5Y cells, increasing apoptotic cell death by more than 50\% (Fig. 4E). Additionally, DAPK1 overexpression plus rotenone treatment triggered a synergistic increase in cell death in SH-SY5Y cells. However, this effect was not seen with the DAPK1-K42A mutant or with siRNA-mediated knockdown of $\alpha$-synuclein (Fig. $4 \mathrm{E})$.

These results suggest that DAPK1 acts as a novel regulator of rotenone-induced cell death in SH-SY5Y cells, potentiating cell death by enhancing toxic $\alpha$-synuclein aggregation and synucleinopathy.

\section{DISCUSSION}

DAPK1 is a mediator of pro-apoptotic pathways and is involved in various cell death processes induced by internal and external apoptotic stimuli $[15,17]$. It regulates both caspase-dependent and autophagic, but caspase-independent, cell death signaling [17] Additionally, DAPK1 suppresses tumor growth and metastasis by promoting autophagy and apoptosis [15]. In numerous cell culture models, DAPK1 has also been implicated in pathways leading to apoptosis and in some cases may function prior to the commitment steps of the signal transduction mechanism [22, 2830]. Thus, some of the apoptotic properties of DAPK1 observed in cultured cells are likely responsible for certain aspects of human diseases. The present findings also verified the previous report that DAPK1 signaling induces synucleinopathy and dopaminergic neuron degeneration in a mouse model of PD [26].

$\alpha$-Synuclein might be a target for a variety of post-translational modifications, including phosphorylation [5, 6], nitrosylation [7], ubiquitination $[8,9]$, and sumoylation [10], which may affect the biochemical properties and function of $\alpha$-synuclein, such as the formation of its toxic aggregates. The most widely studied reaction is the phosphorylation of $\alpha$-synuclein that occurs at Ser129 [31]. Within the $\alpha$-synuclein protein there are four Ser residues that are potential phosphorylation sites, of which Ser129 is the most important and influential for LB formation and PD pathogenesis [6]. Phosphorylation of $a$-synuclein at Ser129 is mediated and regulated by various kinases. For example, casein kinase and polo-like kinase are representative kinase that facilitate $\alpha$-synuclein phosphorylation at Ser129 [32-34]. In addition to these enzymes, the present study identified another kinase of $\alpha$-synuclein, DAPK1, that mediates Ser129-phosphorylation. In addition to oligomerization and aggregation, phosphorylation of Ser129 alters the physiological functions of $a$-synuclein in mammalian cells. For example, the binding of $a$-synuclein to membranes was significantly weakened 
A

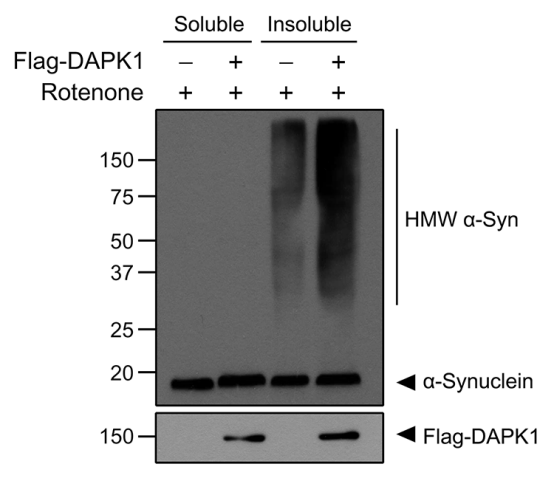

B

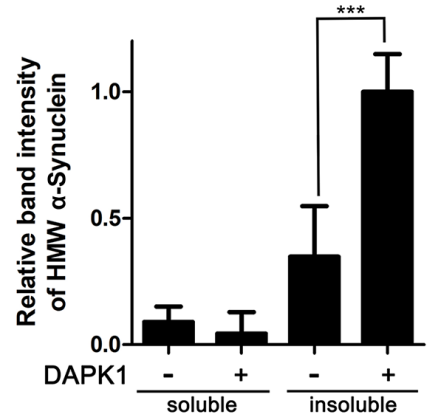

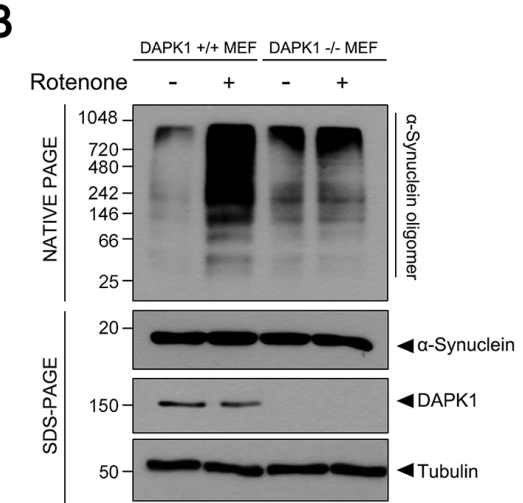
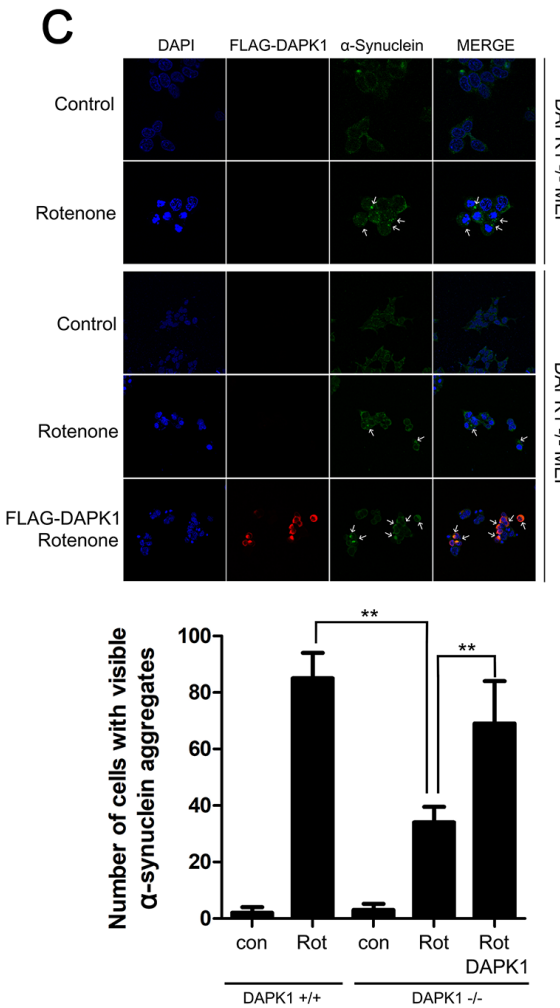

D
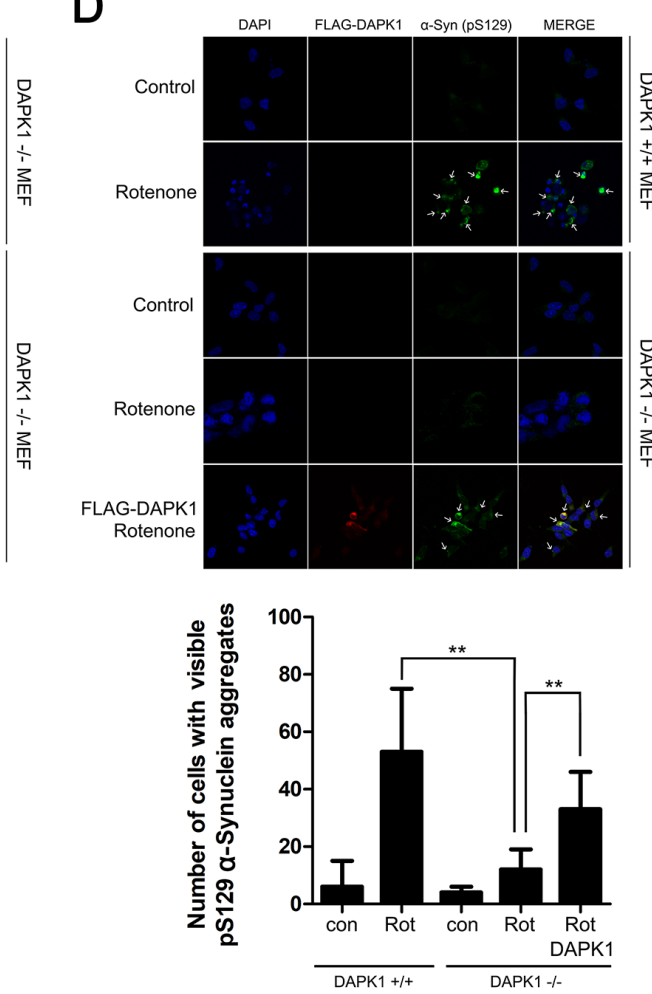

E
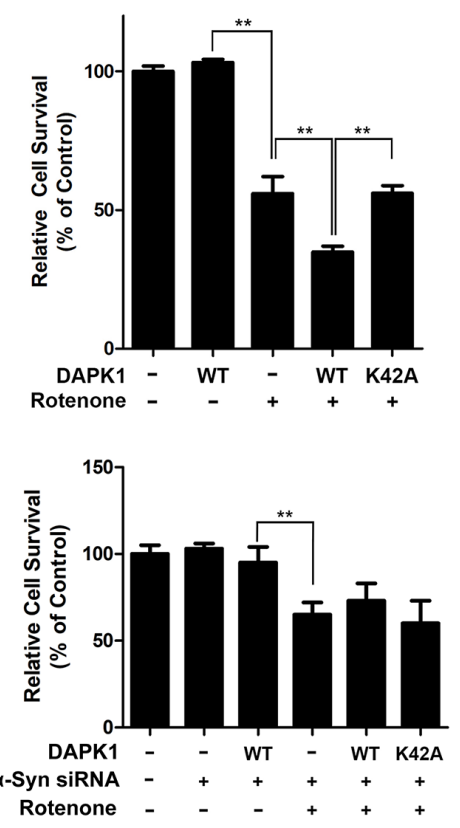

Fig. 4. DAPK1 exacerbates rotenone-induced toxic synucleinopathy in SH-SY5Y and MEF cells. (A) SH-SY5Y cells were either mock-transfected or transfected for $24 \mathrm{~h}$ with a plasmid encoding FLAG-DAPK1-WT, and treated with $100 \mathrm{nM}$ rotenone for additional $24 \mathrm{~h}$. Cell lysates were fractionated into $1 \%$ Triton X-100-soluble and -insoluble fractions, followed by immunoblotting with the indicated antibodies. (B) DAPK1-WT or DAPK1-KO MEFs were treated with either DMSO (control) or $100 \mathrm{nM}$ rotenone for $24 \mathrm{~h}$. Cells were lysed with detergent-free lysis buffer and the protein samples were analyzed by native PAGE. (C) After DAPK1-WT or DAPK1-KO MEFs were mock transfected or transfected for $24 \mathrm{~h}$ with a plasmid encoding FLAG-DAPK1-WT, cells were treated with either DMSO (control) or $100 \mathrm{nM}$ rotenone for an additional $24 \mathrm{~h}$. Representative confocal images of immunostaining of endogenous $\alpha$-synuclein (green) and FLAG-DAPK1 (red) are shown in the upper panel. In the lower panel, the number of cells showing intracellular and visible $\alpha$-synuclein aggregates were counted among $\sim 100$ cells, and this was repeated five times. Data represent the mean \pm SEM of five independent experiments ( ${ }^{* *} \mathrm{p} \leq 0.01$ ). (D) Where indicated, DAPK1-WT or DAPK1-KO MEFs were mock-transfected or transfected for $24 \mathrm{~h}$ with a plasmid encoding FLAG-DAPK1-WT, and treated with either DMSO (control) or $100 \mathrm{nM}$ rotenone for additional 24 h. Representative confocal images of immunostaining of pS129- $\alpha$-synuclein (green) and FLAG-DAPK1 (red) are shown in the upper panel. In the lower panel, the number of cells showing intracellular and visible $\alpha$-synuclein aggregates was counted in approximately 100 cells, and the counting was repeated five times. The data represent the mean \pm SEM of five independent experiments $\left({ }^{* *} \mathrm{p} \leq 0.01\right.$ ). (E) Where indicated, SH-SY5Y cells were transfected for $24 \mathrm{~h}$ with plasmids encoding FLAGDAPK1-WT or FLAG-DAPK1-K42A, or $\alpha$-synuclein $(S N C A)$ siRNA alone or in combination. Cells were then treated with either DMSO (control) or $100 \mathrm{nM}$ rotenone for an additional $24 \mathrm{~h}$. Cell viability was measured using Cell Counting Kit- 8 . Data represent the mean \pm SEM of five independent experiments $\left({ }^{* *} \mathrm{p} \leq 0.01\right)$. 
by Ser129-phosphorylation [35, 36]. The subcellular localization of $\alpha$-synuclein was also changed by phosphorylation, resulting in the increased presence of $\alpha$-synuclein within the nuclear side [37]. Interestingly, $90 \%$ of $\alpha$-synuclein found in LBs is phosphorylated [38], and phosphorylation of a-synuclein at Ser129 is associated with neurodegeneration in the rat PD model $[39,40]$. Our data further support the hypothesis that DAPK1 plays an important role in $\alpha$-synuclein-mediated neurodegeneration, and possibly in the pathogenesis of PD.

DAPK1 is widely known as a tumor suppressor that modulates cell survival and death in a variety of cell systems. Moreover, accumulating evidence has shown that apoptotic neuronal death is regulated by DAPK1, and defective DAPK1 function is associated with NDDs [19, 21, 22, 30]. For example, DAPK1 plays a role in brain stroke by interacting with NMDA receptors [41]. In addition, DAPK1 activity negatively regulates spatial memory in mice [42]. In AD, DAPK1 increases the phosphorylation of AD-related tau, thereby increasing the accumulation of tau inclusions and toxicity [24]. DAPK1 also induces the phosphorylation of APP at Thr668, whereas DAPK1-KO mice displayed a reduction in the amyloidogenic processing of APP [25]. Furthermore, single-nucleotide polymorphisms in DAPK1 are associated with late-onset $\mathrm{AD}[43,44]$. In PD, the brains of PD model mice showed increased levels of DAPK1, and upregulation of DAPK1 induced degeneration of dopaminergic neurons, synucleinopathy, and $\alpha$-synuclein phosphorylation at Ser129 [26]. While these reports suggest the close association between DAPK1 and NDDs, it is not clearly defined whether the phosphorylation and toxicity of $\alpha$-synuclein is increased by DAPK1 in neuronal cells. The current data validate this hypothesis, illustrating that DAPK1 markedly increases the phosphorylation of $a$-synuclein at Ser129 in human neuroblastoma SH-SY5Y cells. The previous study using PD animal model did not examine the possibility whether DAPK1 could modify other Ser residue(s) within the a-synuclein [26]. Our results with in vitro kinase assay confirmed that DAPK1 specifically phosphorylates $\alpha$-synuclein on Ser129 among the four targets, subsequently promoting the insoluble $\alpha$-synuclein aggregation. Because it was known that phosphorylation of $\alpha$-synuclein at Ser 129 is associated with neuronal toxicity of $\alpha$-synuclein, especially with dopaminergic neuronal cell death, these data also proposed that the physiological function of DAPK1 might be important in the regulation of neuronal cell toxicity of intracellular $\alpha$-synuclein and its aggregates. While the direct link between DAPK1 and the formation of toxic aggregates containing pSer129- $\alpha$-synuclein was not also verified in the previous report [26], we demonstrated that DAPK1 facilitates the formation of pSer129- $\alpha$-synuclein-including aggregate and exacerbates neuronal cell death under rotenone treatment in SH-SY5Y cells.

The formation of insoluble aggregates and LBs is a good indicator of the neuronal toxicity of $\alpha$-synuclein. As hyperphosphorylated $\alpha$-synuclein accumulated excessively and makes up the majority of $\alpha$-synuclein in LBs [38], the increase in $\alpha$-synuclein phosphorylation by DAPK1 would be expected to augment the formation of $\alpha$-synuclein aggregates. This hypothesis was confirmed by the filter trap and native PAGE analyses, showing that DAPK1 increases the amount of $\alpha$-synuclein aggregates in SH-SY5Y cells through a-synuclein phosphorylation at Ser129. Moreover, DAPK1-mediated phosphorylation was shown to be essential to the formation of intracellular $\alpha$-synuclein inclusions. Lastly, we demonstrated that the production of insoluble $\alpha$-synuclein aggregates by DAPK1 exacerbates apoptotic SH-SY5Y cell death under conditions of rotenone treatment.

In conclusion, the present study revealed that DAPK1 plays an important role in stimulating toxic $\alpha$-synuclein aggregation and neuronal cell death.

\section{ACKNOWLEDGEMENTS}

The authors thank T.H. Lee for providing plasmids, DAPK1-KO (DAPK1-/-), and control (DAPK1+/+) MEFs. This work was supported by the grants from the Korea Healthcare Technology R\&D Project through the Korea Health Industry Development Institute (KHIDI), funded by the Ministry \& Welfare, Republic of Korea (HI17C0936 to K.C.C.) and from National Research Foundation of Korea (NRF) funded by the Ministry of Science, ICT \& Future Planning (2018R1A2B2003955 to K.C.C.). This work was also supported in part by Brain Korea 21 (BK21) PLUS program and W.H.S is a fellowship awardee by BK21 PLUS program.

\section{REFERENCES}

1. Olanow CW, Tatton WG (1999) Etiology and pathogenesis of Parkinson's disease. Annu Rev Neurosci 22:123-144.

2. Spillantini MG, Schmidt ML, Lee VM, Trojanowski JQ, Jakes R, Goedert M (1997) Alpha-synuclein in Lewy bodies. Nature 388:839-840.

3. Kahle PJ, Neumann M, Ozmen L, Müller V, Odoy S, Okamoto N, Jacobsen H, Iwatsubo T, Trojanowski JQ, Takahashi H, Wakabayashi K, Bogdanovic N, Riederer P, Kretzschmar HA, Haass C (2001) Selective insolubility of alpha-synuclein in human Lewy body diseases is recapitulated in a transgenic mouse model. Am J Pathol 159:2215-2225.

4. Volles MJ, Lansbury PT Jr (2003) Zeroing in on the pathogenic form of alpha-synuclein and its mechanism of neuro- 
toxicity in Parkinson's disease. Biochemistry 42:7871-7878.

5. Okochi M, Walter J, Koyama A, Nakajo S, Baba M, Iwatsubo T, Meijer L, Kahle PJ, Haass C (2000) Constitutive phosphorylation of the Parkinson's disease associated alpha-synuclein. J Biol Chem 275:390-397.

6. Smith WW, Margolis RL, Li X, Troncoso JC, Lee MK, Dawson VL, Dawson TM, Iwatsubo T, Ross CA (2005) Alpha-synuclein phosphorylation enhances eosinophilic cytoplasmic inclusion formation in SH-SY5Y cells. J Neurosci 25:5544-5552.

7. Giasson BI, Duda JE, Murray IV, Chen Q, Souza JM, Hurtig HI, Ischiropoulos H, Trojanowski JQ, Lee VM (2000) Oxidative damage linked to neurodegeneration by selective alphasynuclein nitration in synucleinopathy lesions. Science 290:985-989.

8. Bennett MC, Bishop JF, Leng Y, Chock PB, Chase TN, Mouradian MM (1999) Degradation of alpha-synuclein by proteasome. J Biol Chem 274:33855-33858.

9. Lee JT, Wheeler TC, Li L, Chin LS (2008) Ubiquitination of alpha-synuclein by Siah-1 promotes alpha-synuclein aggregation and apoptotic cell death. Hum Mol Genet 17:906-917.

10. Oh Y, Kim YM, Mouradian MM, Chung KC (2011) Human Polycomb protein 2 promotes a-synuclein aggregate formation through covalent SUMOylation. Brain Res 1381:78-89.

11. Dexter DT, Jenner P (2013) Parkinson disease: from pathology to molecular disease mechanisms. Free Radic Biol Med 62:132-144.

12. Fujiwara H, Hasegawa M, Dohmae N, Kawashima A, Masliah E, Goldberg MS, Shen J, Takio K, Iwatsubo T (2002) alphaSynuclein is phosphorylated in synucleinopathy lesions. Nat Cell Biol 4:160-164.

13. Takahashi M, Kanuka H, Fujiwara H, Koyama A, Hasegawa M, Miura M, Iwatsubo T (2003) Phosphorylation of alphasynuclein characteristic of synucleinopathy lesions is recapitulated in alpha-synuclein transgenic drosophila. Neurosci Lett 336:155-158.

14. Neumann M, Kahle PJ, Giasson BI, Ozmen L, Borroni E, Spooren W, Müller V, Odoy S, Fujiwara H, Hasegawa M, Iwatsubo T, Trojanowski JQ, Kretzschmar HA, Haass C (2002) Misfolded proteinase K-resistant hyperphosphorylated alpha-synuclein in aged transgenic mice with locomotor deterioration and in human alpha-synucleinopathies. J Clin Invest 110:1429-1439.

15. Bialik S, Kimchi A (2006) The death-associated protein kinases: structure, function, and beyond. Annu Rev Biochem 75:189-210.

16. Deiss LP, Feinstein E, Berissi H, Cohen O, Kimchi A (1995) Identification of a novel serine/threonine kinase and a novel
$15-\mathrm{kD}$ protein as potential mediators of the gamma interferon-induced cell death. Genes Dev 9:15-30.

17. Singh P, Ravanan P, Talwar P (2016) Death associated protein kinase 1 (DAPK1): a regulator of apoptosis and autophagy. Front Mol Neurosci 9:46.

18. Inbal B, Bialik S, Sabanay I, Shani G, Kimchi A (2002) DAP kinase and DRP-1 mediate membrane blebbing and the formation of autophagic vesicles during programmed cell death. J Cell Biol 157:455-468.

19. Sulaiman Alsaadi M (2019) Role of DAPK1 in neuronal cell death, survival and diseases in the nervous system. Int J Dev Neurosci 74:11-17.

20. Pei L, Shang Y, Jin H, Wang S, Wei N, Yan H, Wu Y, Yao C, Wang X, Zhu LQ, Lu Y (2014) DAPK1-p53 interaction converges necrotic and apoptotic pathways of ischemic neuronal death. J Neurosci 34:6546-6556.

21. Fujita Y, Taniguchi J, Uchikawa M, Endo M, Hata K, Kubo T, Mueller BK, Yamashita T (2008) Neogenin regulates neuronal survival through DAP kinase. Cell Death Differ 15:15931608.

22. Pelled D, Raveh T, Riebeling C, Fridkin M, Berissi H, Futerman AH, Kimchi A (2002) Death-associated protein (DAP) kinase plays a central role in ceramide-induced apoptosis in cultured hippocampal neurons. J Biol Chem 277:1957-1961.

23. Wu PR, Tsai PI, Chen GC, Chou HJ, Huang YP, Chen YH, Lin MY, Kimchi A, Chien CT, Chen RH (2011) DAPK activates MARK1/2 to regulate microtubule assembly, neuronal differentiation, and tau toxicity. Cell Death Differ 18:1507-1520.

24. Kim BM, You MH, Chen CH, Lee S, Hong Y, Hong Y, Kimchi A, Zhou XZ, Lee TH (2014) Death-associated protein kinase 1 has a critical role in aberrant tau protein regulation and function. Cell Death Dis 5:e1237.

25. Kim BM, You MH, Chen CH, Suh J, Tanzi RE, Ho Lee T (2016) Inhibition of death-associated protein kinase 1 attenuates the phosphorylation and amyloidogenic processing of amyloid precursor protein. Hum Mol Genet 25:2498-2513.

26. Su Y, Deng MF, Xiong W, Xie AJ, Guo J, Liang ZH, Hu B, Chen JG, Zhu X, Man HY, Lu Y, Liu D, Tang B, Zhu LQ (2019) MicroRNA-26a/death-associated protein kinase 1 signaling induces synucleinopathy and dopaminergic neuron degeneration in Parkinson's disease. Biol Psychiatry 85:769-781.

27. Sugeno N, Takeda A, Hasegawa T, Kobayashi M, Kikuchi A, Mori F, Wakabayashi K, Itoyama Y (2008) Serine 129 phosphorylation of alpha-synuclein induces unfolded protein response-mediated cell death. J Biol Chem 283:23179-23188.

28. Raveh T, Droguett G, Horwitz MS, DePinho RA, Kimchi A (2001) DAP kinase activates a p19ARF/p53-mediated apop- 
totic checkpoint to suppress oncogenic transformation. Nat Cell Biol 3:1-7.

29. Jang CW, Chen CH, Chen CC, Chen JY, Su YH, Chen RH (2002) TGF-beta induces apoptosis through Smad-mediated expression of DAP-kinase. Nat Cell Biol 4:51-58.

30. Yamamoto M, Hioki T, Ishii T, Nakajima-Iijima S, Uchino S (2002) DAP kinase activity is critical for C(2)-ceramideinduced apoptosis in PC12 cells. Eur J Biochem 269:139-147.

31. Anderson JP, Walker DE, Goldstein JM, de Laat R, Banducci K, Caccavello RJ, Barbour R, Huang J, Kling K, Lee M, Diep L, Keim PS, Shen X, Chataway T, Schlossmacher MG, Seubert P, Schenk D, Sinha S, Gai WP, Chilcote TJ (2006) Phosphorylation of Ser-129 is the dominant pathological modification of alpha-synuclein in familial and sporadic Lewy body disease. J Biol Chem 281:29739-29752.

32. Waxman EA, Giasson BI (2011) Characterization of kinases involved in the phosphorylation of aggregated $\alpha$-synuclein. J Neurosci Res 89:231-247.

33. Kosten J, Binolfi A, Stuiver M, Verzini S, Theillet FX, Bekei B, van Rossum M, Selenko P (2014) Efficient modification of alpha-synuclein serine 129 by protein kinase CK1 requires phosphorylation of tyrosine 125 as a priming event. ACS Chem Neurosci 5:1203-1208.

34. Inglis KJ, Chereau D, Brigham EF, Chiou SS, Schöbel S, Frigon NL, Yu M, Caccavello RJ, Nelson S, Motter R, Wright S, Chian D, Santiago P, Soriano F, Ramos C, Powell K, Goldstein JM, Babcock M, Yednock T, Bard F, Basi GS, Sham H, Chilcote TJ, McConlogue L, Griswold-Prenner I, Anderson JP (2009) Polo-like kinase 2 (PLK2) phosphorylates alpha-synuclein at serine 129 in central nervous system. J Biol Chem 284:25982602.

35. Nübling GS, Levin J, Bader B, Lorenzl S, Hillmer A, Högen T, Kamp F, Giese A (2014) Modelling Ser 129 phosphorylation inhibits membrane binding of pore-forming alpha-synuclein oligomers. PLoS One 9:e98906.

36. Kuwahara T, Tonegawa R, Ito G, Mitani S, Iwatsubo T (2012) Phosphorylation of $\alpha$-synuclein protein at Ser- 129 reduces neuronal dysfunction by lowering its membrane binding property in Caenorhabditis elegans. J Biol Chem 287:70987109.

37. Schell H, Hasegawa T, Neumann M, Kahle PJ (2009) Nuclear and neuritic distribution of serine-129 phosphorylated alphasynuclein in transgenic mice. Neuroscience 160:796-804.
38. Schlossmacher MG, Frosch MP, Gai WP, Medina M, Sharma N, Forno L, Ochiishi T, Shimura H, Sharon R, Hattori N, Langston JW, Mizuno Y, Hyman BT, Selkoe DJ, Kosik KS (2002) Parkin localizes to the Lewy bodies of Parkinson disease and dementia with Lewy bodies. Am J Pathol 160:16551667.

39. Sato H, Arawaka S, Hara S, Fukushima S, Koga K, Koyama S, Kato T (2011) Authentically phosphorylated $\alpha$-synuclein at Ser129 accelerates neurodegeneration in a rat model of familial Parkinson's disease. J Neurosci 31:16884-16894.

40. Gorbatyuk OS, Li S, Sullivan LF, Chen W, Kondrikova G, Manfredsson FP, Mandel RJ, Muzyczka N (2008) The phosphorylation state of Ser-129 in human alpha-synuclein determines neurodegeneration in a rat model of Parkinson disease. Proc Natl Acad Sci U S A 105:763-768.

41. Tu W, Xu X, Peng L, Zhong X, Zhang W, Soundarapandian MM, Balel C, Wang M, Jia N, Zhang W, Lew F, Chan SL, Chen Y, Lu Y (2010) DAPK1 interaction with NMDA receptor NR2B subunits mediates brain damage in stroke. Cell 140:222-234.

42. Yukawa K, Tanaka T, Bai T, Li L, Tsubota Y, Owada-Makabe K, Maeda M, Hoshino K, Akira S, Iso H (2006) Deletion of the kinase domain from death-associated protein kinase enhances spatial memory in mice. Int J Mol Med 17:869-873.

43. Li Y, Grupe A, Rowland C, Nowotny P, Kauwe JS, Smemo S, Hinrichs A, Tacey K, Toombs TA, Kwok S, Catanese J, White TJ, Maxwell TJ, Hollingworth P, Abraham R, Rubinsztein DC, Brayne C, Wavrant-De Vrièze F, Hardy J, O'Donovan M, Lovestone S, Morris JC, Thal LJ, Owen M, Williams J, Goate A (2006) DAPK1 variants are associated with Alzheimer's disease and allele-specific expression. Hum Mol Genet 15:25602568.

44. Li H,Wetten S, Li L, St Jean PL, Upmanyu R, Surh L, Hosford D, Barnes MR, Briley JD, Borrie M, Coletta N, Delisle R, Dhalla D, Ehm MG, Feldman HH, Fornazzari L, Gauthier S, Goodgame N, Guzman D, Hammond S, Hollingworth P, Hsiung GY, Johnson J, Kelly DD, Keren R, Kertesz A, King KS, Lovestone S, Loy-English I, Matthews PM, Owen MJ, Plumpton M, PrysePhillips W, Prinjha RK, Richardson JC, Saunders A, Slater AJ, St George-Hyslop PH, Stinnett SW, Swartz JE, Taylor RL, Wherrett J, Williams J, Yarnall DP, Gibson RA, Irizarry MC, Middleton LT, Roses AD (2008) Candidate single-nucleotide polymorphisms from a genomewide association study of Alzheimer disease. Arch Neurol 65:45-53. 